\title{
医療機器の市販後安全について \\ Post Market Vigilance/Surveillance for Medical Devices
}

\author{
谷城 博幸(正会員)* \\ Hiroyuki TANISHIRO*
}

\begin{abstract}
The Pharmaceuticals and Medical Devices Agency (PMDA) has focused on the three areas for adverse health effects, reviews, and post-marketing safety measures, encompassing the entire life cycle of drugs and medical devices from development through post-marketing surveillance. Although regarding the review process of medical devices, the activity of PMDA has been well-known, regarding the post-marketing safety measures for medical devices, the activity has not. The post-marketing safety measure means taking measures for minimizing the risk of the adverse events in medical devices use. In this report, the author explains especially the post-marketing measure for medical devices, and it provides topics of interest for the development and modification of the new medical devices.
\end{abstract}

\section{Key Words}

Post Market, Medical Devices Safety, Vigilance, Surveillance

\section{1. はじめに}

(独) 医薬品医療機器総合機構(以下, PMDA)では, 医薬 品・医療機器の審査, 市販後の安全対策, 健康被害救済の3 業務を柱として行っている. PMDA における医療機器の審査 については, 少なからず知られていると思われるが, 医療機器 の市販後安全対策といわれると, 一体どういうことを行っている のか, 一般に馴染みが薄いように思われる. 医療機器の市販後 安全対策とは,「市販されている医療機器を使用する上で起こ った不具合・有害事象に対して, そのリスクを最小限に抑えるた めの安全上の対策を講じる」ことである.この市販後安全対策 は, PMDA だけが考えることではなく, それぞれの立場は違っ ていても, 医療機器を使用する医療従事者や医療機器を製造 販売する医療機器メーカも一緒に考えていかなければならない ことであり, 最終的には, 医療機器を使用して診断や治療を受 ける患者のリスクの低減に貢献するものである.

では, 具体的に安全対策を考えるといっても, どこまでの対策を とれば「安全」といえるのか, これは医療機器に限らず非常に難 しいテーマであり, 医療機器メーカが「ここまでの安全対策をと っていれば大丈夫」と思っていたことが，医療現場では十分と

2010 年 9 月 19 日 第 26 回ライフサポート学会大会にて講演 2010 年 12 月 27 日 原稿受理

* (独) 医薬品医療機器総合機構 安全第一部医療機器安全 課, テ100-0013 東京都千代田区霞が関 3-3-2

*Office of Safety I, Pharmaceuticals and Medical Devices Agency (PMDA), Kasumigaseki3-3-2, Chiyoda-ku, Tokyo, 100-0013
思われていなかったということにしばしば遭遇する。「安全」とは, 極めて抽象的で定性的な言葉であり, ここでいう「安全」とは, 安全に必要となる要素を多角的・定量的に評価することによっ て, ある一定の範囲でここまでなら大丈夫と確認されたこととし か言いようがないのである.

本報告では，医療機器の市販後の安全対策について例をあ げて紹介し, 経験した安全対策上の課題を踏まえて, 将来の医 療機器の開発や改良につなげていくことができる話題を提供で きればと考える。

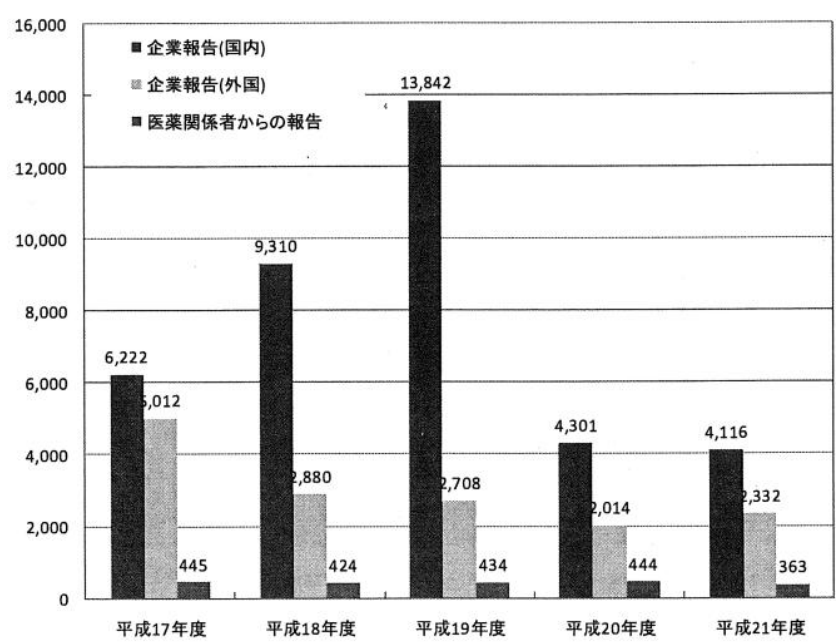

Fig.1 Adverse Event Annual Report of Medical Devices $^{1)}$ 


\section{2. 不具合報告の実際}

平成 17 年から平成 21 年度にPMDAに報告された医療機器 の不具合報告の推移を Fig.1 に示した.ここで企業報告となっ ているものは, 薬事法に基づいて医療機器メーカから報告され たもの, 医薬関係者からの報告となっているものは, 医師, 薬剤 師, 看護師, 臨床工学技士, リスクマネージャ等の医療従事者 からの報告である. 国内外あわせて年閒約 7 千件程度で推移 しており,これらの報告の個々の概要は, PMDA のホームペー ジから閲覧可能である.

医療機器の審査が扱う医療機器は俗に「承認品」といわれる, 承認を必要とする一部の機器のみであるが, 市販後の安全で 扱う医療機器は, 第三者認証機関で認証基準に基づいて審査 される「認証品」やPMDAに販売許可の届出を行う「届出品」を 含めて, 市場に流通している全ての医療機器が対象となる. 従 つて, 不具合報告される医療機器と不具合の内容については, 例えば, 輸液・輸血に使用されるチューブ類の接続部分の外れ から, 心臓ペースメーカの機能停止, 薬剤溶出ステントの破損 やステント血栓など, 多岐にわたっている.

\section{3. 不具合報告の分析と安全対策の検討}

不具合報告の分析の手法として用いられる最も容易なパラメ 一夕は不具合の発生率や発生件数であるが, それだけでは安 全対策の必要性を単純に判断できないのが現実である.

例えば, 医療機器の機能や品質に問題はなくても医療機器 を使用する医師の技量に左右されることがある. 同じ医療機器 を使用していたとしても，ある特定の医療機関では不具合の発 生件数が増加しているにもかかわらず, 他の医療機関では不
具合が起こっていないこともあり, 全体の不具合件数を見るより も, 詳細に個々の医療機関の使用状況に応じた検討を考える 必要がある.また一方で, 医療機器の使用方法に問題がなか ったとして, 医療機器の物理的な問題や使用状況で論理的に 再現性が生じる不具合であれば, 例え不具合が一件しか報告 されていなくても, 他の多くに波及することを想定して, 全体的 な対策が必要となる場合がある.

PMDA では, このような不具合の発生状況に鑑み, 報告され ている不具合については発生率や発生件数だけではなく, 医 療機器の種類, 医療従事者の使用状況, 患者の状態などを総 合的に判断し, 不具合に基づくリスクを最小限に抑えるための バランスのよい安全対策を検討する必要があり, 必要に応じて, 医療機関や医療機器メ一力, 専門家とも協力し, 情報収集・情 報交換を行っている(Fig.2 参照).

\section{4. バランスのよい安全対策とは何か}

医療機器の構造上の欠陥や, 故障などはその部分を是正す る対策をとればよいわけだが，中にはその対策をどこまで行え ばよいのか, なかなか見当がつかないこともある。

例えば，経皮的インターベンション (PCI) に用いられるカテ 一テルを血管内に誘導するためのガイドワイヤの破断強度のチ エック方法は, JIS 規格 2)で定められており, ガイドワイヤに約 $1 \mathrm{~kg}$ のおもりをぶら下げてもコアワイヤとコイル (Fig.3 参照)が 切れないといらものである. 市販されているガイドワイヤはマージ ンをとって,この規格に示された数倍程度の破断強度をもつが， 規格に該当しているこのガイドワイヤで不具合が起こったことを 想定して, 考えられる対策を色々と考えてみようと思う.

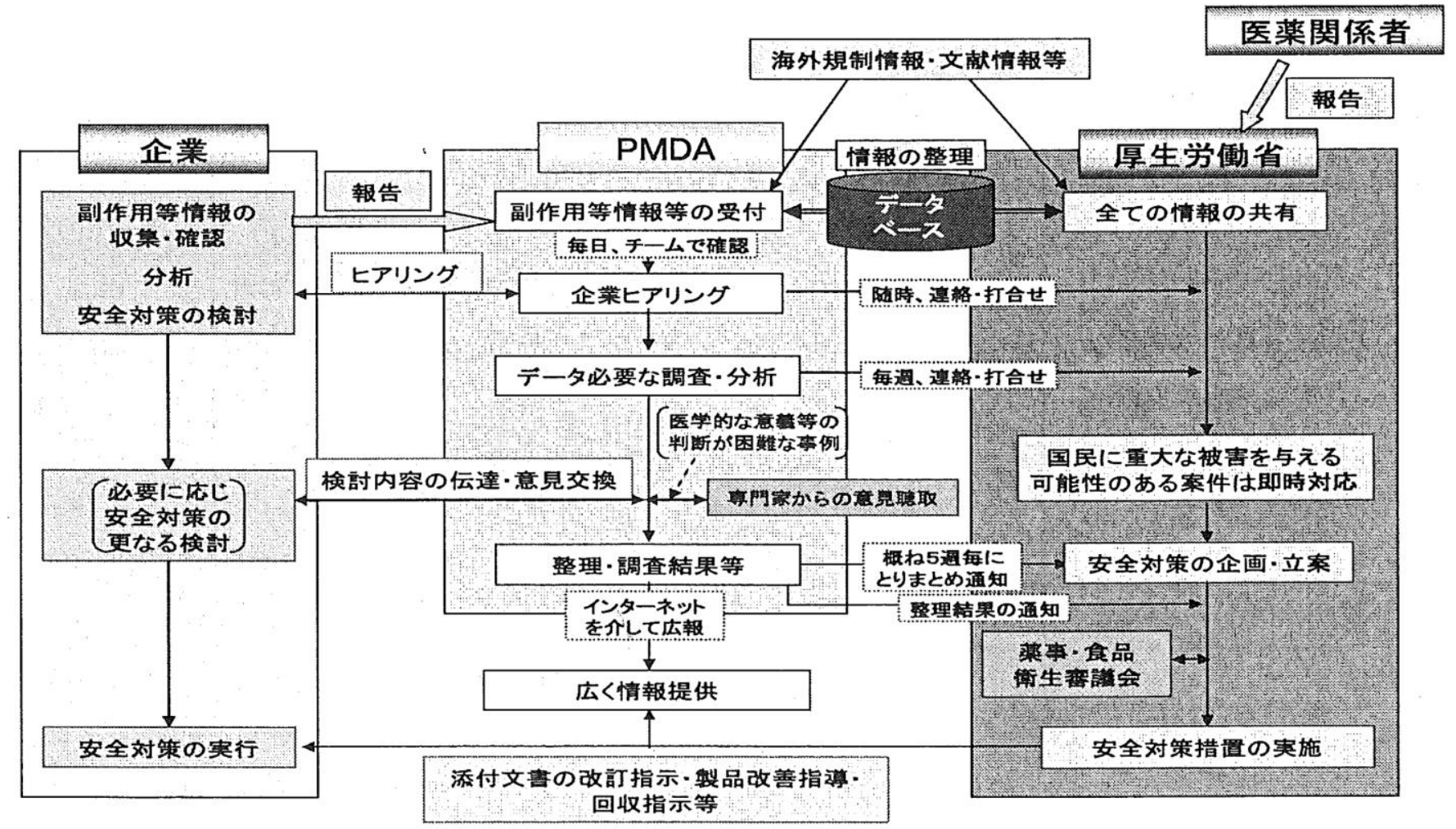

Fig.2 Medical Devices Post Marketing Safety of PMDA 1) 


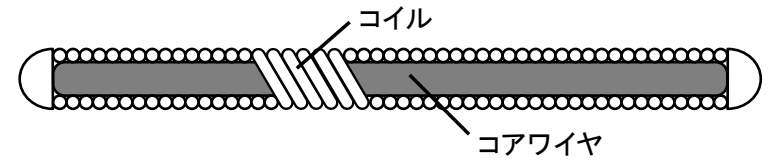

Fig.3 Structure of PCI Guide-Wire

\section{不具合事象の例:}

PCI で冠動脈ステントを留置するために, 血管内にガイド ワイヤを挿入した. カテーテルをガイドワイヤに沿わせて病 変部まで誘導したところ, 患者の血管にある石灰化部分に カテーテルがスタックした. スタックを解除しようと試みたが, このまま施術を続行することは無理と判断, カテーテルとガ イドワイヤを体外に抜去しようとしたところ, ガイドワイヤが破 断してしまった.

ここで,このガイドワイヤは仮に規格以上の $1.5 \mathrm{~kg}$ のおもりを つけても切れない強度を持っていたとする.この製品自体に品 質上の問題はなく, 破断したとすれば, スタックしたガイドワイヤ を解除しようと試みた医師は, $1.5 \mathrm{~kg}$ 以上の力をガイドワイヤに かけ続けたといらことになるのだが, 今後このようなことが起こら ないようにするためにはどのような対策が検討される必要がある だろうか. 医療機器メーカの対策について考えてみると,

医療機器メーカの対策の例:

(1)ガイドワイヤの破断強度を上げて, 切れないようにする

(2) 添付文書の改訂を行い, $1.5 \mathrm{~kg}$ 以上の力で引つ張らな いように医療従事者への注意喚起をする

などが考えられる.

（1）については, 破断強度を上げるために材質を変えるなど の工夫をしたときに, 複雑な冠動脈の血管走行にあわせてガイ ドワイヤを曲げるためのしなやかさやねじれにかかる特性が変 化しないとも限らない. 簡単に破断強度を上げることのみではな く, ガイドワイヤ全体としての機能を損なわない改善を行わなけ ればならず, 対策を講じるには総合的な検討が必要となり, 通 常はある程度の時間を要するため, 短期的な対策とはなり難い. （2）については, 血管の石灰化の状態や血管の細さなど, ガイ ドワイヤの操作上 $1.5 \mathrm{~kg}$ 以上の力がかかるともかぎらないと考え られるが, $1.5 \mathrm{~kg}$ の力がかからないように例えば, バネばかりを つけてガイドワイヤにかかるテンションを量って $1.5 \mathrm{~kg}$ 以上の力 をかけないように医療従事者が心がけるというようなことは, 手技 中には無理な方法である.

では, 医療機器メーカとして出来る速やかな対策は何かという と, ごく当たり前のことになるが, ガイドワイヤは使用状況によっ ては破断する可能性があること, 破断に至った場合のフォロー として, その破断片を回収できる方法を添付文書などに明示し, 医療従事者に正しく伝えることが重要となる.

次に, PMDA の対策について考えてみると,

\section{PMDA の対策の例:}

(1) 破断強度の JIS 規格の見直しを検討する

（2）医療従事者への使用上の注意などの注意喚起・情報 提供を行う
などが考えられる.

（1）については, 規格に示された破断強度がいかなる過程に よって定められたか知る必要がある. 元々, JIS については, 「工業標準化の意義は, 具体的には, 自由に放置すれば, 多 様化, 複雑化, 無秩序化してしまう「もの」や「事柄」について, 経済・社会活動の利便性の確保(互換性の確保等), 生産の効 率化 (品種削減を通じての量産化等), 公正性を確保 (消費者 の利益の確保, 取引の単純化等), 技術進歩の促進 (新しい知 識の創造や新技術の開発・普及の支援等), 安全や健康の保 持, 環境の保全等のそれぞれの観点から, 技術文書として国レ ベルの「規格」を制定し，これを全国的に「統一」又は「単純化」 すること」3)とされており, 様々な指標を元に, 個々の製品の JIS 規格が定められている.ガイドワイヤの破断強度については, 少なからず, JIS 規格を制定するときに元々市場にあった各ガ イドワイヤ製品の破断強度試験などを参考に定められたもので ある.この JIS 規格を改定し, 医療機関などでの使用状況を鑑 み, どんな種類のガイドワイヤであっても破断の不具合が頻発 するようであれば, 破断強度の基準をあげるなど, 規格の見直 し等へ不具合の情報をフィードバックする必要があると考える. （2）については, 医療機器メ一力単独の注意喚起・情報提供に 加えて, 広く医療機関に情報を提供する場合などがこれに当た る. 事案によっては, 厚生労働省を通じて, 医療機器メーカとと もに医療従事者への情報を「通知」4) という形で広く情報提供す No.8 2009年 2月
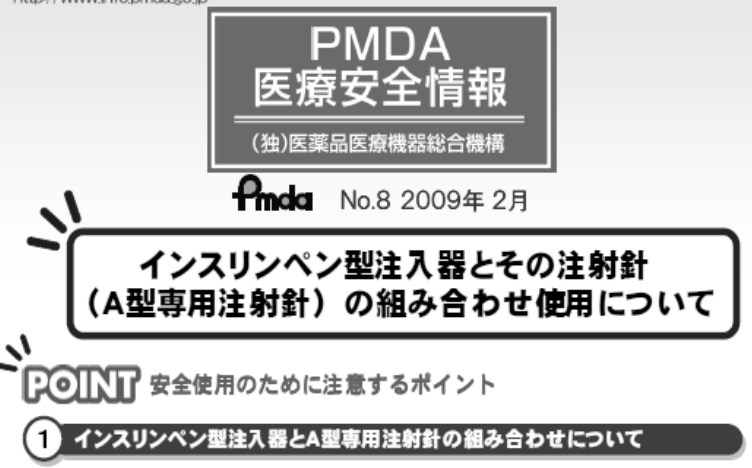

・これまで、各社インスリンペン型注入器(カートリッジ式・キッ外式)には、それぞれの

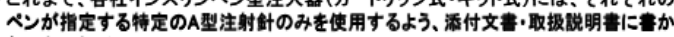
れておりました。

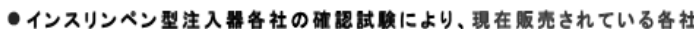

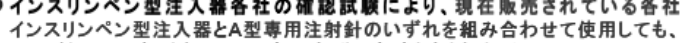

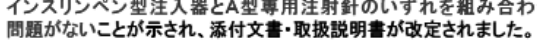

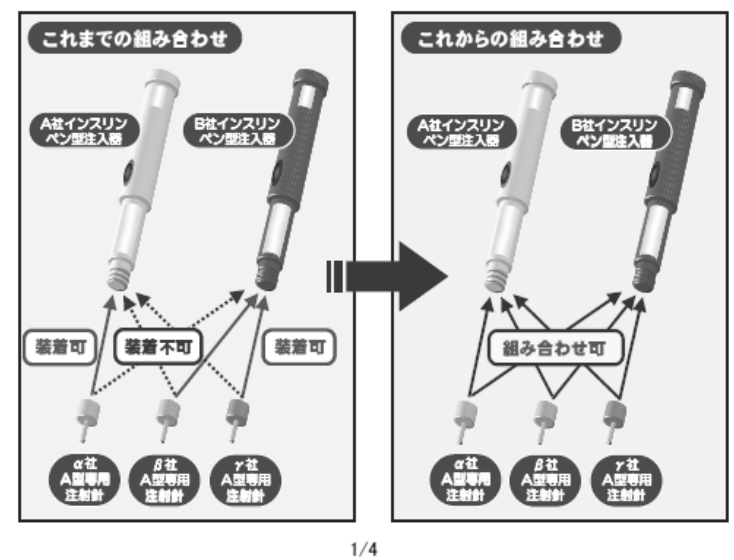

Fig.4 PMDA Medical Safety Information ${ }^{5)}$ 


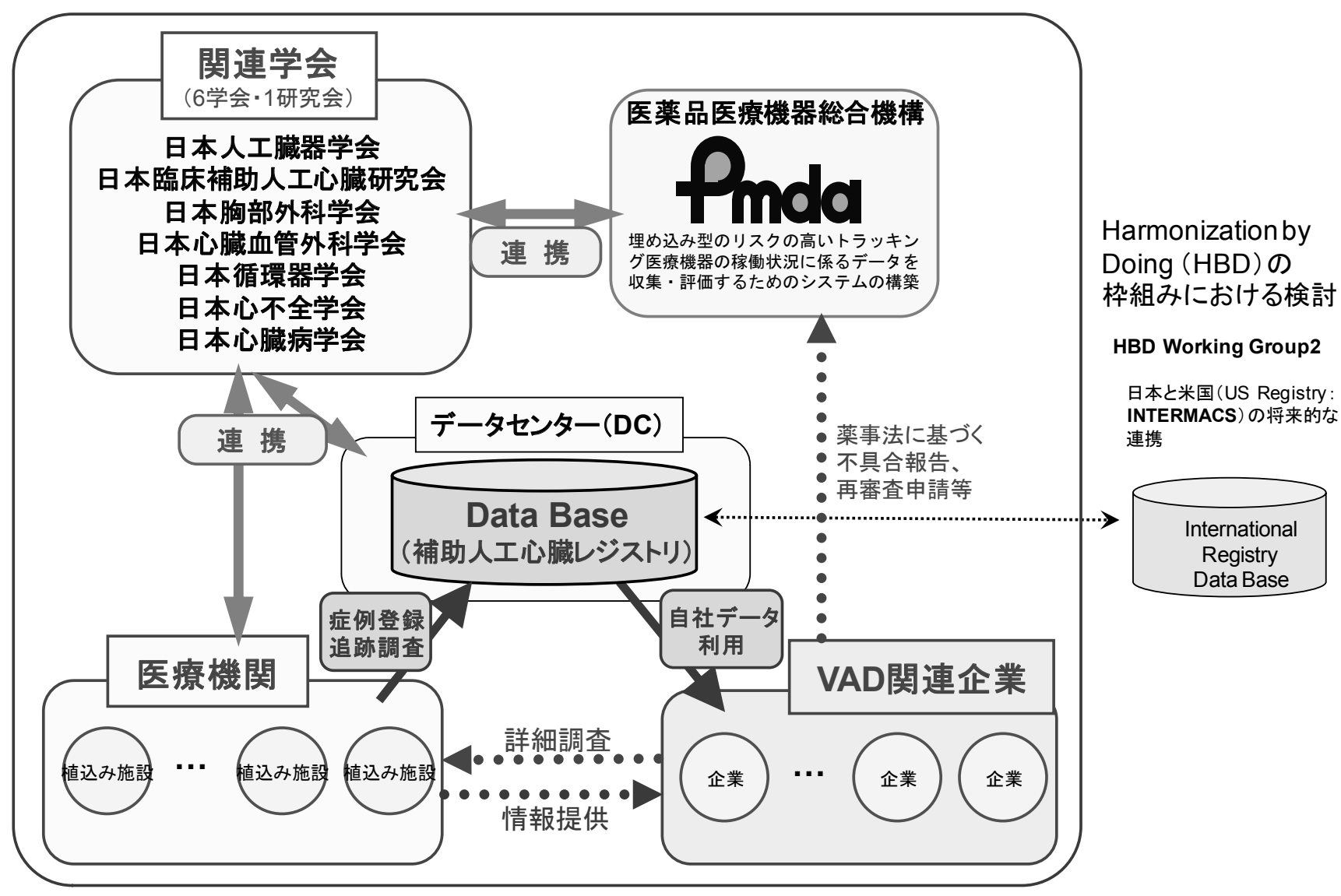

Fig.5 J-MACS Organization ${ }^{1)}$

る場合や, PMDA が発行する「PMDA 医療安全情報」5)を通じ て情報提供する場合がある(Fig.4 参照).ただし, いずれの安 全対策とも, 医療機器メ一力や学会などと協力し, 現実的な安 全対策を講じる必要があると考える.

つづいて，医療機関での対策を考えてみると，

医療機関の対策の例 :

(1) 使用状況の再確認と医療機器メーカや PMDA への必 要な情報のフィードバック

(2) 適正な使用方法の徹底と患者へのインフォームドコンセ ント

などが考えられる.

(1)については, 今後の類似の不具合に対する安全対策へ の情報源として有用な情報であり,「ガイドワイヤが切れた」とい うだけの情報ではなく, 出来る限り使用状況や製品の状態を医 療機器メーカへ提供すること, また, 医療機関報告を通じて PMDA に必要な情報を報告してもらうことが重要である.（2）に ついては, 医療従事者の使用状況がその医療機器に明示され た使用方法と異なる場合に, そもそもどちらの使用状況が適正 なものなのかを見極め, 医療従事者が使用方法を改める必要 性があるのか, 医療機器メー力側で事実にそぐわない使用方法 を改める必要があるのかをよく検討しなければならない. また, PCI で冠動脈治療を行うベネフィットを患者に伝えることは, 患 者に安心感を与えることにおいて有益と考えられるが, 治療に 伴うリスク, 患者の病変部の状態によってはガイドワイヤが切れ
ることがあるということなども, インフォームドコンセントの中で十 分に医療従事者と患者との間で相互理解が得られるようにする ことが重要であると考える.

このように, ガイドワイヤの破断を1つの不具合の例として, 様々な立場での安全対策を考えてみたわけであるが, これらの 安全対策が全て取られたとしても, 決して十分な安全対策であ るとは限らず, あらゆる医療機器の不具合において, バランスの 良い安全対策を講じることはさらに極めて複雑, 難題であること は言うまでもない。

\section{PMDA での新しい試み}

医療機器が承認を受ける際に必要となる医療機器の使用成 績などのデータ, いわゆる治験のデータについては, 特定の病 院において治験プロトコルに基づいたデータ(不具合も含む)が 収集されるため, 不具合に関わる詳細な使用状況などのデータ が入手しやすい. 一方, 市販後の不具合の報告については, 医療機器メーカや医療機関からの情報が元になるが, 先にも述 べたように, 安全対策に必要となる十分な情報が得られないこ とが多々ある. また, 治験では想定されない未知の不具合が生 じたりすることも市販後の実際である. 従って, 治験に準ずるよう な市販後の不具合の情報が収集でき, その詳細な情報から安 全対策を立案できるような方策を検討するための PMDA での 新しい試みがいくつか実施されており, その一つが「日本にお ける補助人工心臓に関連した市販後のデータ収集」 (J-MACS: Japanese Registry for Mechanically Assisted Circulatory Support)である(Fig.5 参照).この J-MACS は 
関倸学会, $\operatorname{VAD}$ (Ventricular Assist Device) 植込み施設, $\mathrm{VAD}$ 関連企業の協力のもと, 産・官・学の連携により, 質の高 い市販後データの収集を可能とし, その分析によって, 日本の VAD における市販後安全の確保や治療の最適化のみならず, 将来的には,このデー夕に基づき次世代 VAD の製品開発の方 向性や治験・承認審查の迅速化にも寄与できるものと期待され る.

\section{6. さいごに}

今回, 医療機器の市販後といらテーマで, PMDA を含めた各 方面での市販後の安全対策について紹介した. 医用・福祉工 学系の学会等で,「ものつくり」が論議される昨今, 今までにな い新しい医療機器の開発に関方る技術や研究をしていくこをも 重要なことであるが, 一つ目先を変えて, 今ある医療機器の機 能の改善・改良に至る方法や, 規格に関連した医療機器に必 要となる試験方法の改善や明確化なども, 研究する余地がある ように思われる. その一つ一つの積み重㸚が, 定性的ではない, より実効性のある「安全」対策の道筋につながることと考えられ る.

参考文献

1) 平成 21 事業年度業務報告, (独) 医薬品医療機器総合機 構, 2010

2) JIST3267:2007 血管用ガイドワイヤ工業規格, 日本工業 標準調查会, 2007

3) 日本工業標準調查会ホームページ, http://www.jisc.go.jp/std/index.html, 2005

4) PMDA ホームページ, 機器安全対策通知, http://www.info.pmda.go.jp/mdevices/mdevices.html, 2010

5) PMDA ホームページ, PMDA 医療安全情報, http://www.info.pmda.go.jp/anzen_pmda/iryo_anzen. html, 2010 